\title{
List of Abbreviations and Note on Citations
}

F

SK

EL

HS

HSP

PF

StA

A for $178 \mathrm{I}$ edition

B for 1787 edition

S
Fichte, Johann Gottlob. Sämmtliche Werke. Ed.

Immanuel Hermann Fichte. 8 vols. Berlin: de Gruyter, I97I.

- The Science of Knowledge (Wissenschaftslehre).

Ed. Peter Heath and John Lachs. Cambridge:

Cambridge University Press, 1982.

Hölderlin, Friedrich. Essays and Letters. Ed. and trans.

by Jeremy Adler and Charlie Louth. London: Penguin, 2009.

- Hölderlin's Sophocles: "Oedipus" and

"Antigone." Ed. and trans. David Constantine.

Hexham, UK, $200 \mathrm{I}$.

- Hyperion and Selected Poems. Ed. Eric Santner. Trans. Richard Sieburth. New York: Continuum, I990. - Poems and Fragments. Ed. and trans. Michael Hamburger. $4^{\text {th }}$ edition. Manchester: Carcanet Press, 2017.

—. Sämtliche Werke. Ed. Friedrich Beißner. 7 vols. Stuttgart: Kohlhammer, I943-1985.

Kant, Immanuel. Kritik der reinen Vernunft, reprinted in vols. 3 and 4 of Kant, Werkausgabe. Ed. Wilhelm Weischedel. I 2 vol. Wiesbaden: Insel Verlag, I960; Critique of Pure Reason. Trans. Paul Guyer and Allen Wood. Cambridge: Cambridge University Press, 1998. Schiller, Friedrich. Werke. Frankfurt am Main: Insel Verlag, 1966.

Whenever parenthetical references to German texts are not followed by references to English editions of Hölderlin's work, translations are the work 
of Julia Ng ("Version of Meaning") or Anthony Curtis Adler ("Parousia, Stone-Walls"). Modifications of published translations are indicated by "mod." Julia Ng's translation of the "third version" of "Der Einzige" (The Only One), as reconstructed by Friedrich Beissner for the Stuttgart edition of Hölderlin's writings, appears as an Appendix and is used throughout the volume. 


\section{TWO STUDIES OF FRIEDRICH HÖLDERLIN}


This page intentionally left blank 